Acta vet. scand. $1964,5,311-330$.

From the Medical Department for Non-Ruminants, Royal Veterinary

College, Stockholm.

\title{
AN INVESTIGATION ON \\ SOW-MILK FAT WITH SPECIAL REFERENCE TO THE FATTY-ACID COMPOSITION*)
}

\author{
By \\ Paul Lindberg and Gunnar Tollerz
}

Most work on the fat composition of milk of domestic animals has been done on cow's milk. Earlier chemical methods for determination of the fatty-acid composition required large samples of milk, which could not be easily collected from sows. De la Mare \& Shorland (1944) examined the fatty acid composition in a pooled sample of milk collected from one sow during a week.

With recently developed methods, such as gas-liquid chromatography, fat analyses can be made on small milk samples. Such an investigation has just been made by de Man \& Bowland (1963) on sows' colostrum and later milk.

The results presented here refer to identified fatty acids and fatty-acid composition, as determined by gas-liquid chromatography, in milk collected during the course of the whole lactation from sows on special diets.

\section{MATERIAL AND METHODS}

Animals. The sows used in the study belonged to the Swedish Land Breed or were crosses between this breed and the English Large White Breed. Some sows had delivered once before and, thus, were in the second lactation period. Others had their first litter. Milk was obtained by stripping a teat while the sow was normally nursing her litter. The release of milk was not artificially stimulated by the use of oxytocin, except for a few cases which are specially noted. A dose of

*) Supported by grants from “Jordbrukets Forskningsråd” and "Anslag för främjande av medicinsk forskning vid Veterinärhögskolan." 
10 I.U. was then given intravenously. A milk volume of $1-3 \mathrm{ml}$ was usually obtained. Samples were taken shortly after the delivery and then at intervals of one or more days during the period of lactation. In one sow, the sampling of milk had to be interrupted after a couple of weeks, because the sow was taken to another experiment which might have influenced the milk composition. One sow became hostile, and no samples could be taken after two weeks. Otherwise the collection was continued until the piglets were weaned at the age of 6-8 weeks. From other sows only a few samples were taken for special purposes.

Composition of diets. Five different diets were used. Diets $A$ and B were commercially available mixtures. C, D, and E were prepared in the laboratory. Ingredients of the different diets are shown in table 1.

T a b l e 1. Composition of the diets (per cent) given to the sows. Adequate amounts of $\mathrm{Ca}, \mathrm{P}$, and trace elements were added.

\begin{tabular}{lrrrrr}
\hline & $\left.\mathrm{A}^{1}\right)$ & $\left.\mathrm{B}^{1}\right)$ & $\mathrm{C}$ & $\mathrm{D}$ & $\mathrm{E}$ \\
\cline { 2 - 6 } Barley & 33 & 44 & 82 & & 18 \\
Oats & 37 & 28 & & 82 & 64 \\
Wheat bran & 15 & 5 & & & \\
Skim-milk powder & & & 18 & 18 & 18 \\
Oil-seed meal, fish and meat meal & 10 & 20 & & & \\
Alfalfa leaf meal & 5 & 3 & & & \\
\hline
\end{tabular}

1) The figures may vary between $\pm 5 \%$ of the absolute amount of each ingredient. Guaranteed to contain no less than 3.0 I.U. of vitamin A, 0.2 I.U. of vitamin $\mathrm{D}_{3}, 2.0 \gamma$ of vitamin $\mathrm{B}_{2}$, and $4.5 \gamma$ of dl-alfatocopheryl acetate per $\mathrm{g}$ of the mixture.

Analytical procedures.

Extraction of lipids from sow's milk and preparation of methyl esters of fatty acids. Lipids were extracted with diethyl ether-ethanol mixture (1:3 by volume). The precipitated protein was removed by filtration, and the soluble extract was then evaporated in vacuo. The residue was extracted with petroleum ether (b.p. $30-60^{\circ} \mathrm{C}$, purified by shaking with concentrated $\mathrm{H}_{2} \mathrm{SO}_{4}, 10 \% \mathrm{NaOH}$ and water, dried with anhydrous $\mathrm{CaCl}_{2}$, and redistilled). The insoluble material was discarded. After evaporation of the petroleum ether in vacuo the lipids were weighed.1)

Methyl esters of fatty acids were prepared by interesterification with $0.5 \mathrm{~N}$ potassium methylate (Luddy et al. 1960).

The purified methyl esters were weighed, ${ }^{1}$ ) solved in petroleum ether, and kept in the refrigerator.

1) Weighed lipids, weighed methyl esters, PFA, and TFA are expressed as percentage $\mathrm{w} / \mathrm{w}$ of dry food substance and of milk, respectively. 
Extraction of lipids and preparation of methyl esters in food were made by the methods described earlier (Lindberg et al. 1964).

Polyunsaturated fatty acids (PFA) were determined enzymatically (Mac Gee 1959).

Total fatty acids (TFA) were calculated from the enzymatically determined PFA value and the relative proportion of PFA of the fatty-acid composition.

Gas-liquid chromatography (GLC). The apparatus used was a Perkin-Elmer $116 \mathrm{E}$ fractometer with hot wire and hydrogen flameionization detectors. $250 \mathrm{~mm}, 2.5 \mathrm{mV}$ Siemens \& Halske recorder for the hot-wire detector and a $120 \mathrm{~mm}, 2.5 \mathrm{mV}$ Siemens \& Halske recorder for the flame-ionization detector were used. The following columns were used:

1. A 2-metre, 5-mm ID standard column P. 20wt-\% polydiethyleneglycol succinate (PDEGS) on 60/80 mesh chromosorb. Column temperature $208^{\circ} \mathrm{C}$. Carrier gas $(\mathrm{He})$, inlet pressure $1 \mathrm{~kg} / \mathrm{c} . \mathrm{cm}$, flow rate $100 \mathrm{ml} / \mathrm{min}$. Sample volume $0.3-1 \mu \mathrm{l}$.

2. A 2-metre, 4-mm ID packed column containing 15wt-\% PDEGS silanized chromosorb W, 60/80 mesh. Column temperature $208^{\circ} \mathrm{C}$. Inlet pressure $1.5 \mathrm{~kg} / \mathrm{c} . \mathrm{cm}$, flow rate $90 \mathrm{ml} / \mathrm{min}$. Sample volume $0.3-1 \mu \mathrm{l}$.

3. A $150 \mathrm{ft}, \mathbf{0 . 0 2}$-inch ID Golay column with $\mathrm{SE}-30$ as liquid phase. Column temperature $208^{\circ} \mathrm{C}$. Inlet pressure $2 \mathrm{~kg} / \mathrm{c.cm}$, flow rate 20 $\mathrm{ml} / \mathrm{min}$. Sample volume $0.2-0.7 \mu \mathrm{l}$.

4. A 2-metre, 4-mm ID packed column containing 2 wt-\% PDEGS on silanized chromosorb W, $60 / 80$ mesh. Column temperature $180^{\circ} \mathrm{C}$. Inlet pressure $1.5 \mathrm{~kg} / \mathrm{c.cm}$, flow rate $70 \mathrm{ml} / \mathrm{min}$. Sample volume $0.1 \mu \mathrm{l}$.

5. A 2-metre, 4-mm ID packed column containing 2 wt- $\%$ Apiezon $\mathrm{L}$ silicon grease on silanized chromosorb W, 60/80 mesh. Column temperature $208^{\circ} \mathrm{C}$. Inlet pressure $1.5 \mathrm{~kg} / \mathrm{c.cm}$, flow rate $80 \mathrm{ml} / \mathrm{min}$. Sample volume $0.1 \mu \mathrm{l}$.

In the first part of the investigation (sows 5, 9, 13, 14, 15, and 16) column 1 was used for routine analysis of the milk samples. Later the somewhat faster column 2 was substituted for column 1 in order to facilitate the determination of acids longer than C 18 (sows 20 and 21). Columns 3-5 were used exclusively for identification purposes.

\section{Identification of methyl esters.}

1. The retention times of the $C 14: 0,15: 0,16: 0,17: 0,18: 0,19: 0$, $16: 1,18: 1,18: 2,18: 3$, and $20: 4$ acids were compared with those of authentic known standards on both polar and non-polar columns.

2. The retention times of methyl esters on polar as well as nonpolar columns were plotted against chain length on semilog. paper.

3. Relationship between retention times in the polar PDEGS and the non-polar SE-30 columns, respectively, was plotted on logarithmic paper. 
4. Hydrogenation was used to distinguish between saturated and unsaturated acids (Farquar et al. 1959). Ethyl alcohol was substituted by methyl alcohol as solvent.

5. Relationship between $\log _{10}$ retention times and number of double bonds at one and the same carbon-chain length.

6. Removal of unsaturated esters as mercuric-acetate adduct (Keeney et al. 1962, Kishimoto \& Radin 1959).

Calculation of methyl-ester composition. Peak areas were determined as the product of peak height and retention time as suggested by Pecsoc (1959) and Carroll (1961). A Perkin-Elmer printing integrator was also used and gave agreeing values. The area of each fatty acid peak was expressed as a percentage of the total peak area for all fatty-acid methyl esters.

The error of analysis of some methyl esters and fat content was determined (Dahlberg 1948). Eight milk samples from altogether 3 sows were divided into two parts, each of which was independently analyzed. The experimental errors are shown below.

\begin{tabular}{lcc} 
& \multicolumn{2}{c}{ Error of analysis } \\
\cline { 2 - 3 } Fatty acids & $\begin{array}{c}\text { relative } \\
\text { percentage }\end{array}$ & $\mathrm{g} / 100 \mathrm{~g}$ milk \\
C $14: 0$ & 0.11 & \\
C $16: 0$ & 0.12 & \\
C $16: 1$ & 0.16 & \\
C $18: 0$ & 0.08 & \\
C $18: 1$ & 0.23 & \\
C $18: 2$ & 0.37 & 0.04 \\
C $18: 3$ & 0.11 & 0.59 \\
PFA & & 0.57 \\
Weighed lipids & & \\
Weighed methyl esters & &
\end{tabular}

\section{RESULTS}

\section{A. Dietary-fat analyses.}

Since it seemed to be important to know the fat content and fatty-acid composition of diets, analyses were made on all diets (table 2). The analyses of $\operatorname{diets} \mathrm{A}, \mathrm{B}$, and $\mathrm{C}$ refer to the complete mixture, but those of $\mathrm{D}$ and $\mathrm{E}$ comprised the grain alone. Skimmilk powder contains negligible amounts $(0.28 \%)$ of fat. The addition of skim-milk powder means, essentially, a proportional decrease of all fat components of the grain when calculated on the basis of mixture weight. To give a more true picture of the diets used, lipid amounts of $\mathrm{D}$ and $\mathrm{E}$ should be multiplied by 
T a b l e 2. Fatty-acid composition of diets. Figures under A, B, and C refer to the complete diets, whereas figures under $D$ and $E$ refer to the grain that was used in the mixture. Individual fatty acids are given as relative percentages.

\begin{tabular}{lrcrrr}
\hline Fatty acids & $\mathrm{A}$ & \multicolumn{1}{c}{$\left.\mathrm{B}^{1}\right)$} & $\mathrm{C}$ & $\mathrm{D}$ & $\mathrm{E}$ \\
\cline { 2 - 6 } $14: 0$ & 1.0 & $0.8(0.7-0.9)$ & 1.0 & 0.1 & 0.1 \\
$16: 0$ & 19.2 & $19.6(19.3-19.9)$ & 21.2 & 15.4 & 16.1 \\
$16: 1$ & 1.2 & $0.9(0.8-0.9)$ & 0.4 & 0.2 & 0.1 \\
$18: 0$ & 1.7 & $2.1(1.9-2.2)$ & 1.7 & 0.6 & 0.6 \\
$18: 1$ & 20.7 & $22.2(21.2-23.0)$ & 13.5 & 36.2 & 38.9 \\
$18: 2$ & 50.6 & $47.3(46.8-48.0)$ & 54.8 & 45.7 & 43.3 \\
$18: 3$ & 5.6 & $7.1(6.7-7.8)$ & 7.5 & 1.2 & 0.9 \\
PFA & 1.72 & $1.24(1.11-1.32)$ & 1.03 & 3.00 & 2.86 \\
& & & & $\left.(2.40)^{2}\right)$ & $(2.29)$ \\
TFA & 3.06 & $2.29(2.00-2.48)$ & 1.65 & 6.40 & 6.47 \\
& & & & $(5.12)$ & $(5.18)$ \\
\hline
\end{tabular}

1) Mean and range of 4 analyses of food mixture taken at different times.

2) Figure within parenthesis are calculated to be valid for the complete diet (cf. the text).

the factor 0.80 . The PFA values will then be 2.40 and 2.29 , and TFA values 5.12 and 5.18 in diets $D$ and $E$, respectively.

Diets $B$ and $C$ are of special interest, as they were given during lactation to the sows used for calculation of the parameters of milk fat (table 5). The main differences are that diet $B$ is richer in fat than is $C$, or 2.29 as against 1.65 per cent of TFA, and that the fat of diet $C$ is relatively more polyunsaturated. The total amount of PFA is somewhat higher in B, however. Diet A, which was given during gestation, has still somewhat higher content of TFA and of PFA than has B. The remarkably high fat content of diets $D$ and $E$ is due to the fact that oats was the main ingredient. The total fatty acids in Swedish oats amounts to $6-8$ per cent, whereas barley contains less than 3 per cent (Lindberg et al., 1964).

\section{B. Milk analyses.}

Identified methyl esters. Altogether 22 methyl esters of fatty acids were identified. They are shown in table 3 . Results obtained in the separation and identification of methyl esters as described 


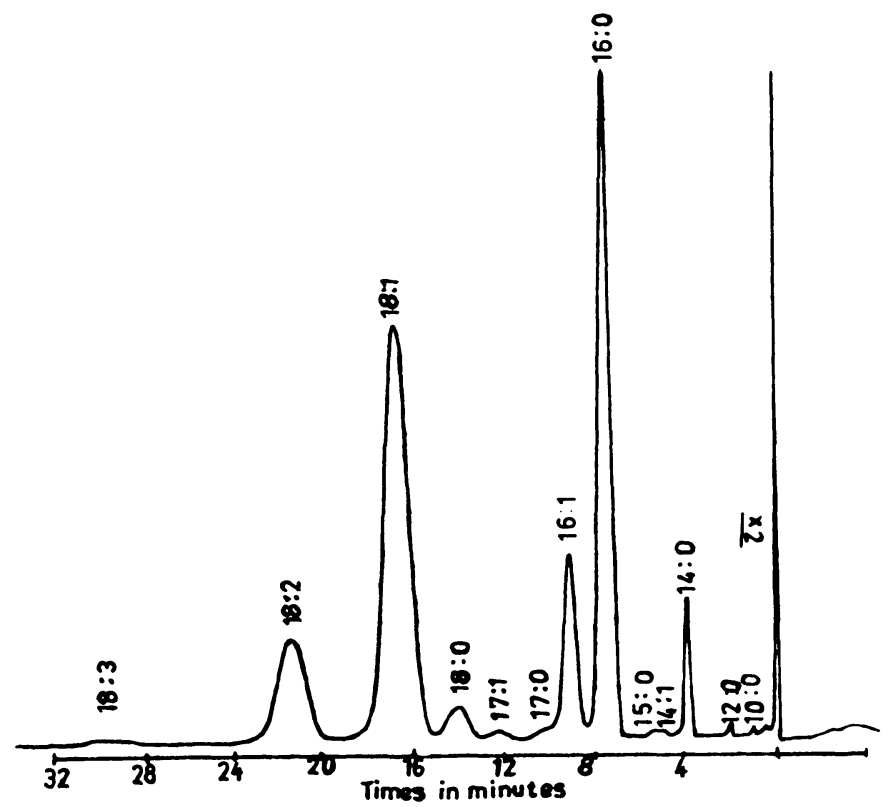

F i g. 1. GLC separation of methyl esters of a milk sample from sow no. 15 , day 18 . Column 1 . Sample volume $0.8 \mathrm{ml}$.

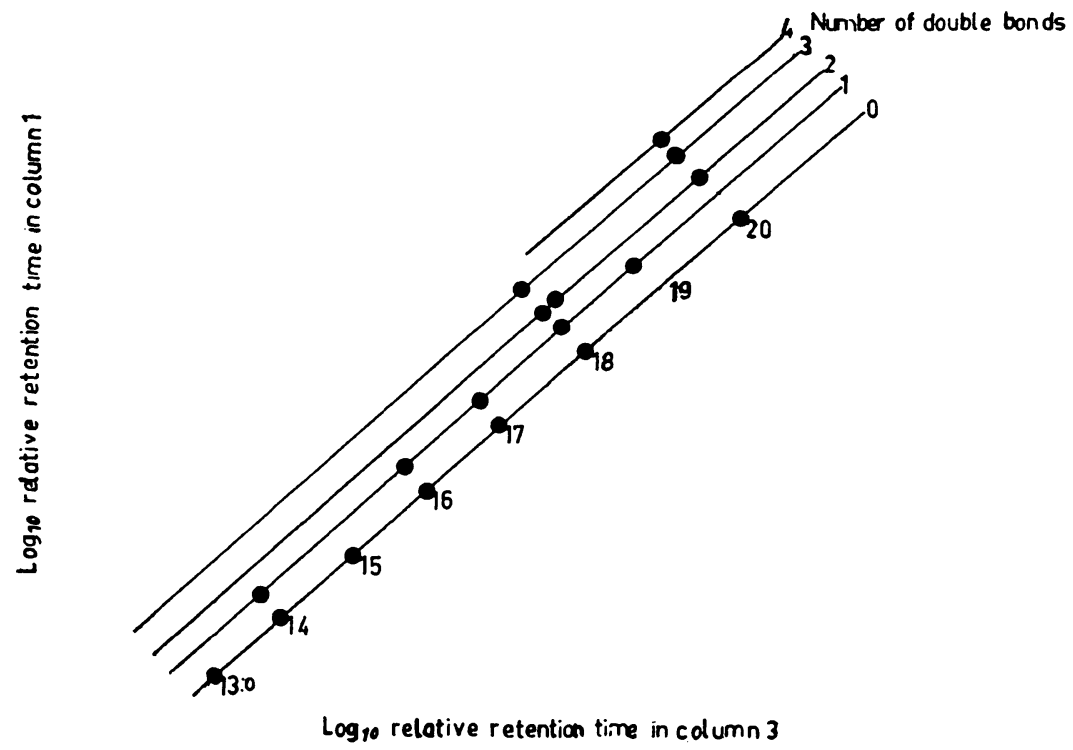

Fig. 2. Relationship between $\log _{10}$ relative retention times of saturated and unsaturated acids in the polar column 1 and the non-polar column 3. 


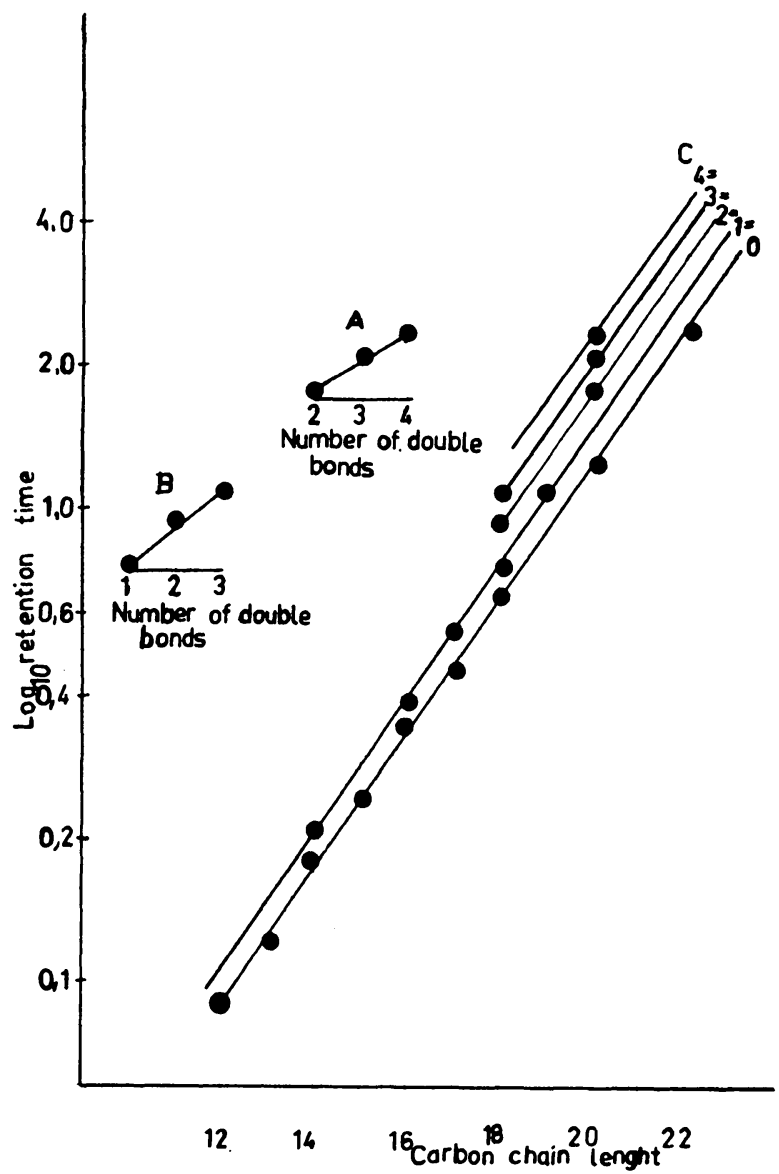

F i g. 3. Relationship between $\log _{10}$ retention times and number of double bonds for the $\mathrm{C} 20$ acids (A), C 18 acids (B), and carbon chain length $(\mathrm{C})$. Column 1.

under Analytical procedures are illustrated by figs. 1-5. Close agreement was found between retention times of identified methyl esters and coresponding known standards.

Fatty-acid composition and lipid contents. After the first 3 days no consistent variation in total fat or fat composition of the milk could be seen. This is illustrated in table 4 , where all values from sow no. 15 are shown. Therefore, the parameters of individual sows on diets $B$ and $C$ in table 5 include all fat determinations from milk taken later than the 3rd day of lactation. There is a considerable variation in the values from time to time. 
318

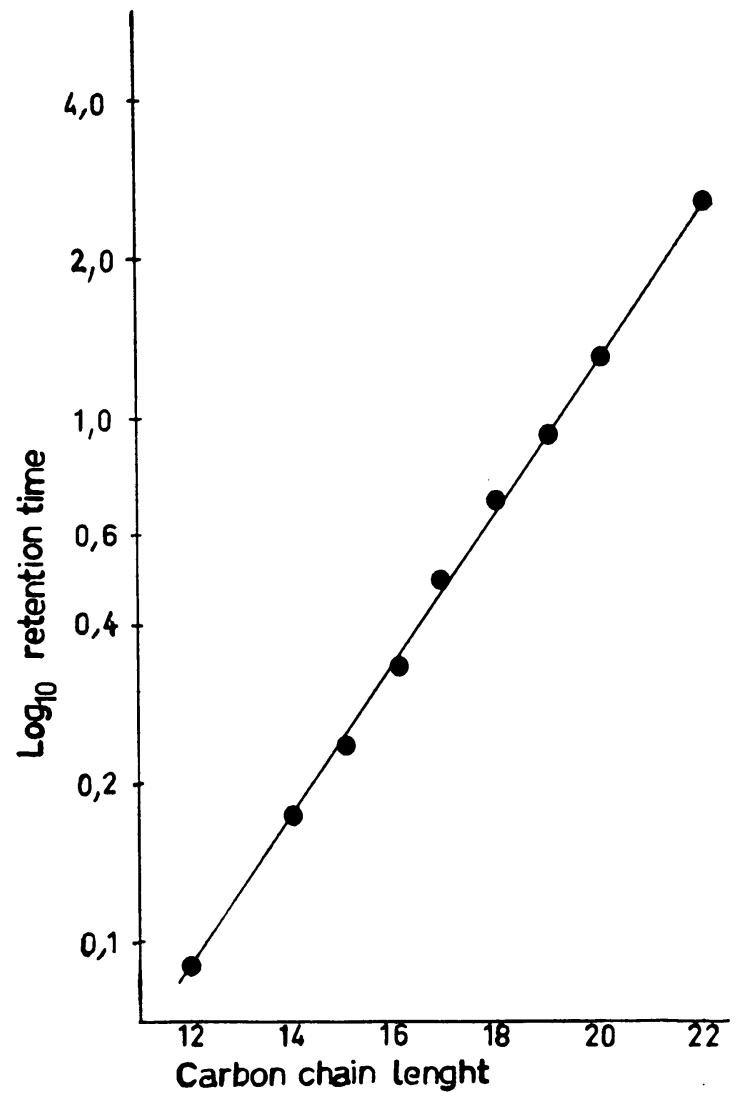

F i g. 4. Relationship between $\log _{10}$ retention times and carbon chain length of hydrogenated methyl esters.

T a b l e 3. Identified methyl esters in sow's milk. Minor unidentified components were situated close to the peak of $\mathrm{C} 18: 3$ after the peak of $\mathrm{C} 22: 0$. The latter probably represent unsaturated $\mathrm{C} 22$ acids.

\begin{tabular}{lccccc}
\hline $\begin{array}{l}\text { Carbon-chain } \\
\text { length }\end{array}$ & 0 & 1 & 2 & 3 & 4 \\
\cline { 2 - 5 } 10 & $\times$ & & & & \\
11 & $\times$ & & & & \\
12 & $\times$ & & & & \\
13 & $\times$ & & & & \\
14 & $\times$ & & & & \\
15 & $\times$ & $\times$ & & & \\
16 & $\times$ & & & & \\
17 & $\times$ & $\times$ & & & \\
18 & $\times$ & $\times$ & & & \\
19 & $\times$ & $\times$ & $\times$ & $\times$ & \\
20 & $\times$ & $\times$ & & & \\
22 & $\times$ & & $\times$ & $\times$ & \\
\end{tabular}




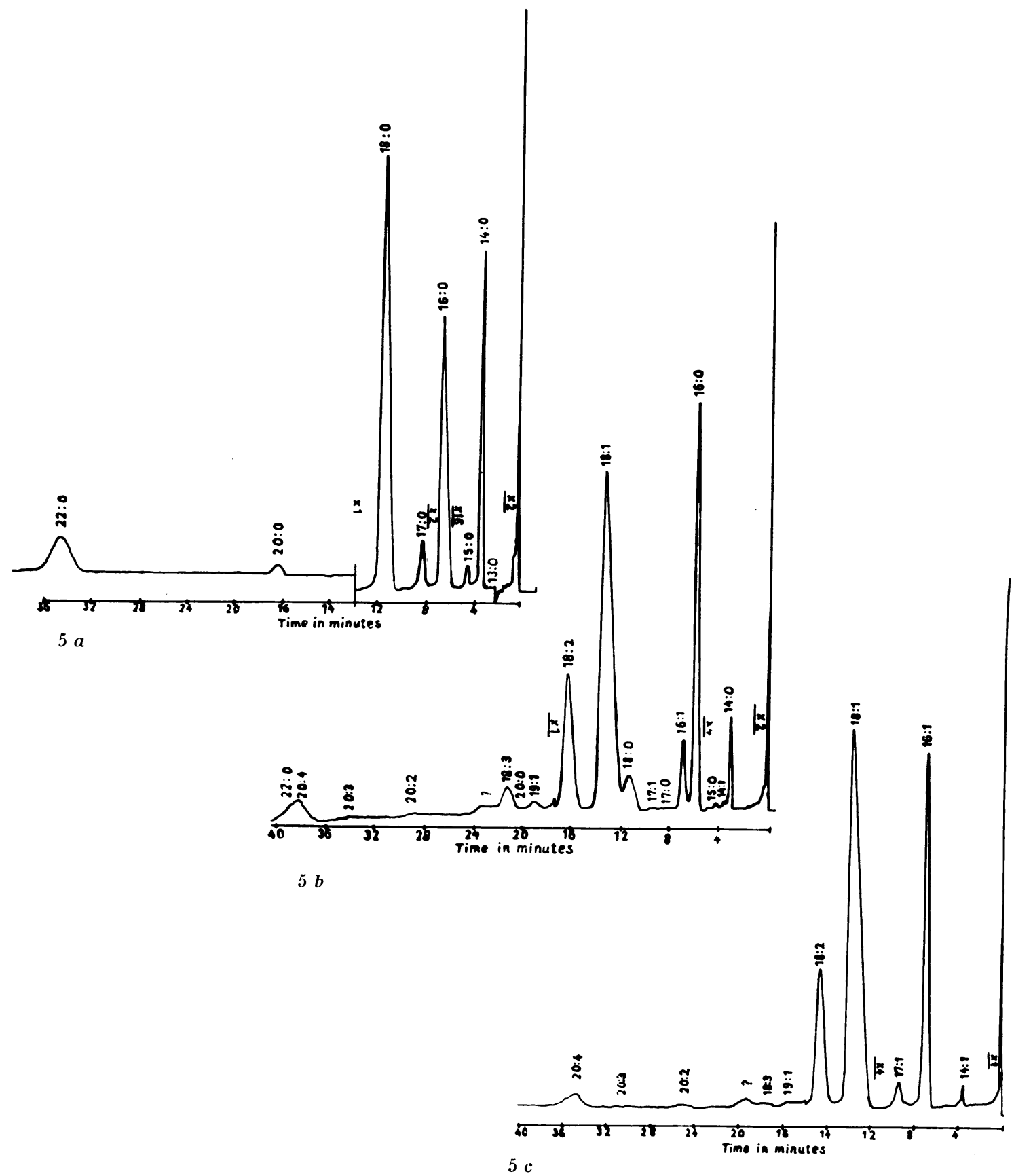

Fig. 5. Separation of saturated (a) and unsaturated (c) esters by the mercuric acetate adduct method. $b$. is the original sample. 


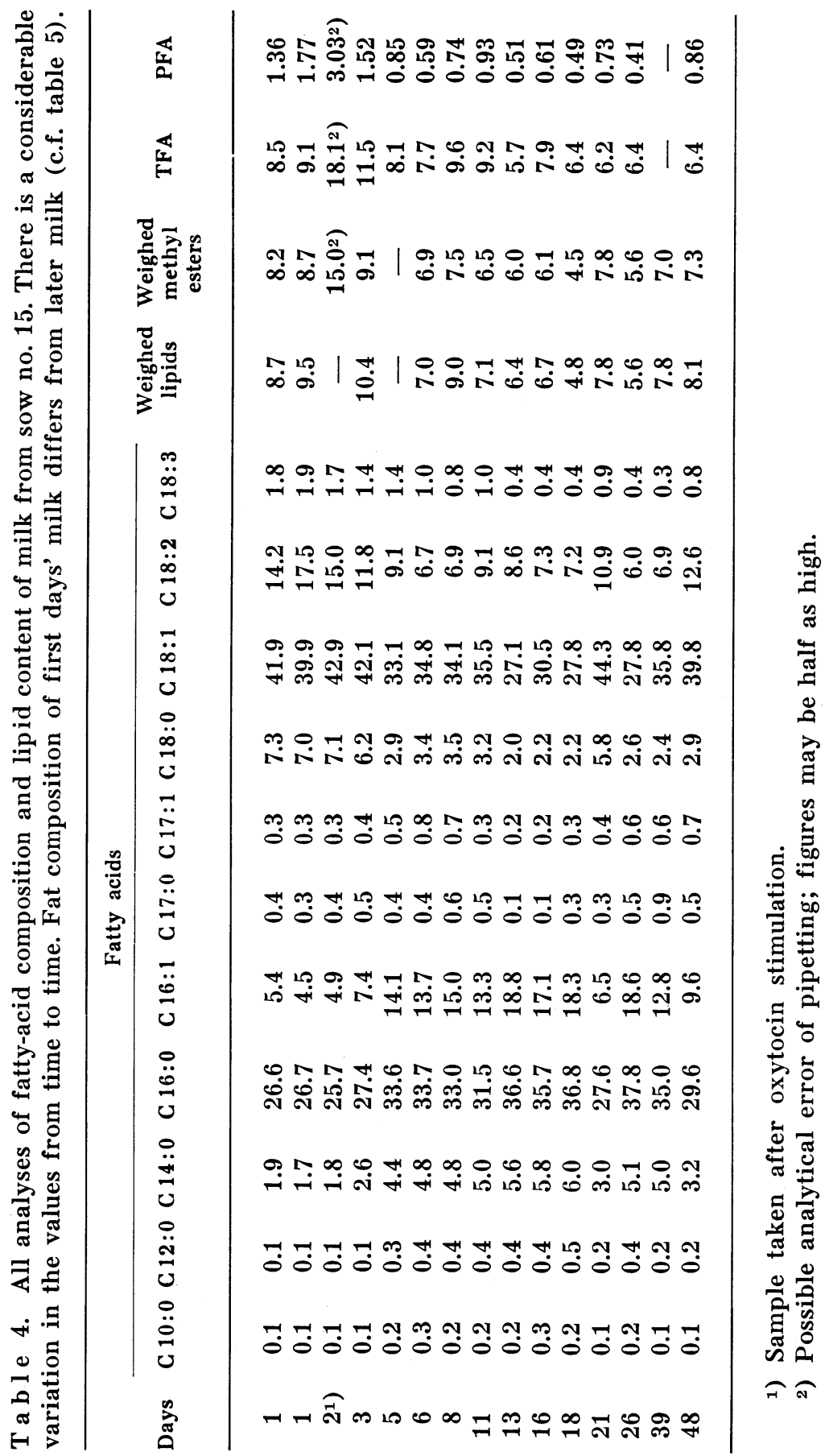




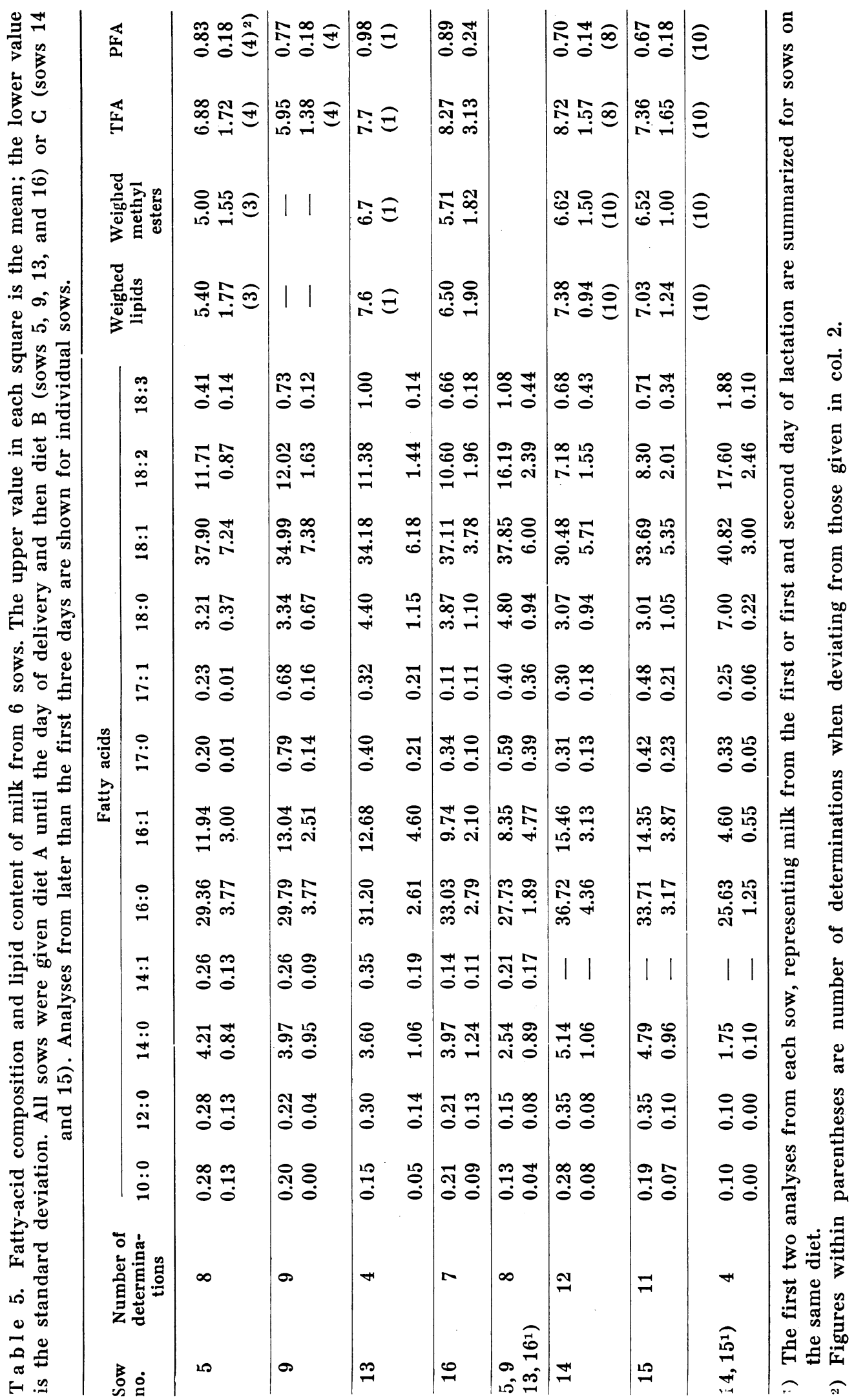




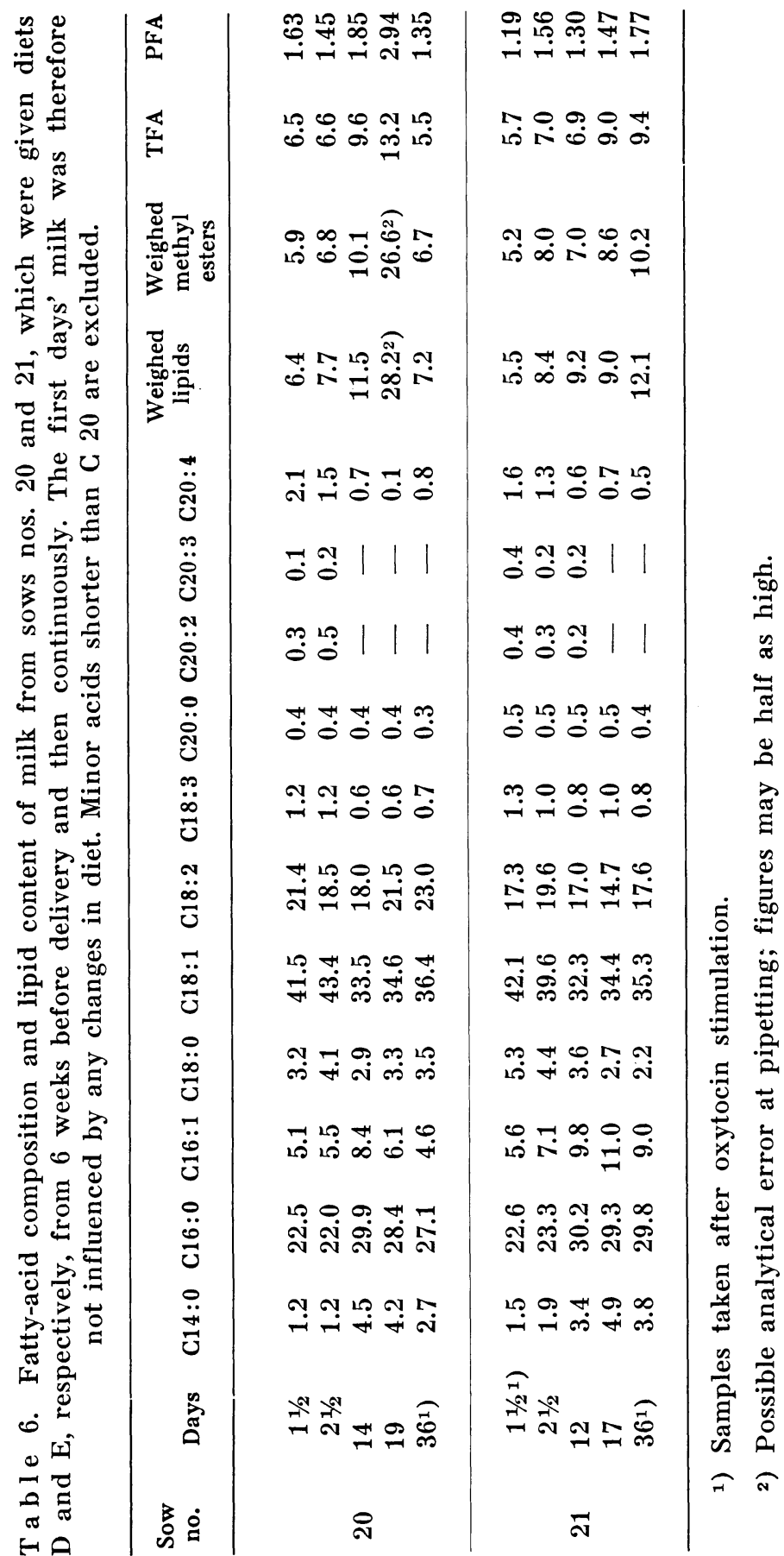


Table 5 also shows the fatty-acid composition of milk from the first two days of lactation. The first two milk samples from each sow are included in these parameters.

Because of differences in fat content and fat composition, and possibly some other differences in diets, the change from $\operatorname{diet} A$ to diets $B$ and $C$, respectively, could have influenced the first days' milk after delivery. It has been shown that a change from high PFA to low, or vice versa, needs 2 to 3 days to be levelled out in the milk-fat picture (Tollerz \& Lindberg, 1965).

In sows nos. 20 and 21, a change of diet was therefore avoided. They were given the same diet ( $D$ and $E$, respectively) from 6 weeks before delivery and then without interruption during the lactation. The results are shown in table 6. Milk from these sows was also used for determinations of acids longer than $\mathrm{C} 18$ with column 2. The fatty-acid picture in the first days' milk differs from that of later milk in principally the same way as for the sows in table 5. In all sows the first days' milk seems to be poorer in $C$ 14:0, $C 16: 0$, and $C 16: 1$ and richer in $C$ 18:0 and $C 18: 1$ than is later milk. Some aspects of the possible influence of diet fat upon milk fat will be further discussed in a subsequent paper (Tollerz \& Lindberg, 1965).

T a b l e 7. Fatty-acid composition and lipid contents of the initial milk (1), a middle fraction (2), and last milk (3) from one milking of sows which were given 10 I.U. of oxytocin intravenously. Minor acids are excluded.

\begin{tabular}{|c|c|c|c|c|c|c|c|}
\hline \multirow[b]{2}{*}{ Fatty acids } & \multicolumn{3}{|c|}{19} & \multicolumn{2}{|c|}{101} & \multicolumn{2}{|c|}{102} \\
\hline & 1 & 2 & 3 & 1 & 3 & 1 & 3 \\
\hline C $14: 0$ & 3.8 & 3.8 & 3.8 & 2.2 & 2.2 & 3.2 & 3.2 \\
\hline C $16: 0$ & 33.9 & 34.0 & 33.7 & 26.0 & 26.1 & 27.4 & 27.3 \\
\hline C $16: 1$ & 6.9 & 6.8 & 6.8 & 5.2 & 5.1 & 9.7 & 9.8 \\
\hline C 18:0 & 4.5 & 4.5 & 4.5 & 5.9 & 6.1 & 3.1 & 3.0 \\
\hline C $18: 1$ & 34.4 & 34.8 & 35.0 & 43.6 & 43.7 & 39.8 & 39.9 \\
\hline C $18: 2$ & 14.7 & 14.5 & 14.8 & 14.7 & 14.8 & 14.5 & 14.7 \\
\hline C $18: 3$ & 0.8 & 0.7 & 0.7 & 0.6 & 0.6 & 1.3 & 1.3 \\
\hline Weighed lipids & 9.0 & 9.9 & 9.8 & 13.3 & 16.9 & 8.4 & 9.8 \\
\hline Weighed & & & & & & & \\
\hline methyl esters & 8.6 & 9.2 & 9.3 & 10.4 & 13.4 & 6.8 & 7.8 \\
\hline TFA & 9.2 & 10.1 & 10.3 & 11.0 & 15.2 & 6.4 & 7.3 \\
\hline PFA & 1.47 & 1.56 & 1.62 & 1.86 & 2.59 & 1.07 & 1.24 \\
\hline
\end{tabular}


Analyses from different fractions of one milking.

If the fat picture should vary during one nursing act, it would influence the results. Sows nos. 19, 101, and 102 were used to check this possibility. Oxytocin was given and the udder was milked empty. The initial milk, in one sow a middle fraction, and last milk ( $5 \mathrm{ml}$ samples) was also analyzed. It will be seen from table 7 that there are very small differences in the fatty-acid composition, but later milk seems to be somewhat richer in fat.

\section{DISCUSSION}

It will be seen from tables 4 and 5 that there is a considerable variation in the fatty-acid composition from time to time in milk of individual sows. It is not unusual that the standard error amounts to about 20 per cent of the mean value. The error of the method is roughly 5-30 times smaller. The variations are therefore conditioned mainly by factors other than errors introduced during the analysis.

The samples were collected without artificial stimulation of milk secretion. The main reason was that we wanted to avoid repeated injections, which would have made the sows hostile and consequently milk samples difficult to obtain after some time. Under the present conditions it was possible with all but one sow, to enter the pen and collect the milk samples during several weeks without interrupting the natural act of nursing.

We also wanted to avoid any possible influence on milk composition from repeated artificial measures. On the other hand, this meant that fairly small samples of milk were obtained each time. A possible disadvantage may be that a small sample is not representative of the whole quantity of milk which is ejected during a period of nursing. A small sample volume might also increase the analytical error. The sample obtained by stripping a teat at the normal nursing probably represents the first milk that the suckling piglets receive. In order to find out whether there were any differences in the milk composition from different fractions of one milking, the experiment shown in table 7 was made. Stimulation with oxytocin had to be used. No significant differences in the fatty-acid composition were observed. There was however, some increase of the fat content from the first to the last fraction in all three sows. There are reasons to suppose that the last milk ejected by oxytocin stimu- 
lation is richer in fat than is the last milk at normal nursing. Oxytocin causes contraction of the myoepithelial cells of the mammae and expels the milk from the smaller ducts. When oxytocin is injected into a cow at the end of milking, further milking will give a new amount of milk which is rich in fat (Knodt \& Petersen, 1944).

Perrin (1954) gave three or four successive injections of oxytocin to sows in order to allow the withdrawal of all their milk. A close examination of her results (cf. table 4, p. 61) also shows an increase of the fat content in the later fractions in comparison with the first one.

Jylling \& Havskov Sфrensen (1960), using oxytocin stimulation, did not observe any regular variation in the milk-fat content of different portions from the same gland in sows. They collected relatively large portions of milk, however. This may have concealed actual differences, which are revealed only by comparing small and instantaneous samples.

It is possible that the fat-content values found by us are a little smaller than the mean value of the whole volume ejected during one nursing. Perrin (1954) found a mean fat value of 9.58 per cent. She cites the earlier literature, which shows a range between 5.29 and 8.17 per cent. On the whole, our values of total lipids compare well with these results.

The error of the method of determination of weighed lipids was comparatively great. It is conceivable that small volumes influence the accuracy of determination. The standard error of determinations of weighed lipids at intervals of days (table 5) is roughly $2-3$ times larger than the error of the method. Thus, only a smaller part of the variations is caused by errors inherent in the method of determination.

When the relatively great time variation in fatty-acid composition and fat content was observed, we decided to examine whether a change to another food mixture would influence this phenomenon. Thus, the simple grain-skimmilk powder mixture $\mathrm{C}$ was used instead of the commercial mixture B (sows 14 and 15, table 5). This does not seem to have altered the magnitude of the variation, however. Therefore the essential cause of variation can hardly be associated with a corresponding variation in the composition of the diet.

Occasionally these variations could be extraordinarily great. There was, for example, an increase in the relative percentage of 
C 18:1 from 27.8 to 44.3 during days $18-21$ (table 4). Corresponding changes appeared at the same time more or less in the whole fatty-acid pattern.

Jylling and Havskov Sфrensen (1960) found no significant differences in fat content between different glands in sows. We did not test this possibility. The teat for taking the sample was chosen at random.

Perrin (1954), using the Gerber test, also observed considerable variations in the fat content of sow's milk from day to day. A comparison shows that her variations generally were of the same order as ours.

By column 1, which was used for sows shown in table 5, acids containing more than 18 carbon atoms, are not discovered. This means, that the relative percentages shown there, should actually be somewhat lower, the sum of the differences making up for about $1-2 \%$. The fact that TFA in tables 4 and 5 mostly is higher than weighed methyl esters is primarily a consequence of the condition that polyunsaturated $\mathrm{C} 20$ acids are not included in the calculations. For sows shown in table 6, however, the fatty acid separation was made by the faster column 2 . This results in a better agreement between TFA and weighed methyl esters.

Folley \& McNaught (1961), in a review on the biosynthesis of milk fat, conclude that the food lipids may contribute around 25 per cent of the milk fatty acids. Whether this proportion is valid for sows is not known. One fraction would be synthetized in the mammary gland, another fraction originating from fatty acids present in the blood. The former mechanism includes a step-wise condensation of acetyl-CoA units to form acids up to $\mathrm{C} 16$, the latter probably providing mainly the $\mathrm{C} 18$ acids. In nonruminants glucose is the essential substrate for the acetate units. It may not be surprising that the complicated process resulting in the milk fat, involving carbohydrate and lipid metabolism, is subjected to considerable physiological variations. Possibly, the synthetic activity of the mammary gland may, for some reason or other, occasionally decrease, leaving more place for the blood fatty acids originating from different fat sources of the body to contribute to the milk fat.

A comparison with the depot fat of pigs (cf. Hilditch, 1956, table 39, p. 107), which had been fed diets with about the same fat content as the present sows, shows that the milk fat contains relatively more $\mathrm{C} 14: 0, \mathrm{C} 16: 0$, and $\mathrm{C} 16: 1$, and respectively less 
$C 18: 0$ and $C 18: 1$. The high content of $C 16: 1$ and the low content of $\mathrm{C}$ 18:0 are particularly striking. Only an approximate comparison can be made owing to the variation between outer and inner depot fat, and the influence of different diets.

An interesting observation will be made if the first days' milk and later milk, respectively, are compared with depot fat (cf. tables 5 and 6 ). The milk obtained within $2 \frac{1}{2}$ days after delivery is poorer in $\mathrm{C} 14: 0, \mathrm{C} 16: 0$, and $\mathrm{C} 16: 1$ (relatively short-chain acids) and richer in $\mathrm{C} 18: 0$ and $\mathrm{C}$ 18:1 (relatively long-chain acids) than is later milk. The differences is thus principally the same as between depot fat and sow's milk. The first days' milk is more similar to depot fat than is later milk. The reason may be that the sows consume less food for a day or two at the time of delivery. The milk fat would originate relatively more from fat depots and probably from synthesis during this time, than from food fat. This assumption is supported by the relative richness of arachidonic acid in the first days' milk (table 6). This acid is not represented in the food and must therefore have been synthetized in the body.

There are no apparent differences between sows given the same diet (cf. sows nos. 5, 9, 13, and 16 in Table 5, and nos. 14 and 15 in the same table). But it is obvious that there are differences between sows given different diets. Of special interest is the difference in the occurrence of $C$ 18:2 when sows are fed $\operatorname{diets} \mathrm{B}, \mathrm{C}, \mathrm{D}$, and $\mathrm{E}$. In a subsequent paper it will be shown that sow's milk is markedly influenced by diets containing high contents of this acid (Tollerz \& Lindberg, 1965).

The generally fatty-acid composition of sow's milk differs from that of cow's milk mainly by an almost complete lack of acids shorter than 14 carbon atoms. The amount of those shortchain acids does not exceed 1 per cent of the fat, whereas the corresponding figure in cow's milk is about 15 per cent. There is also less $C$ 14:0 and $C$ 18:0 in sow's milk. This is counterbalanced by a greater proportion of $\mathrm{C} 16: 1, \mathrm{C} 18: 1, \mathrm{C} 18: 2$, and C 18:3. A comparison with human milk shows only small differences. Human milk is somewhat richer in $\mathrm{C} \mathrm{10-14}$ acids but much poorer in $\mathrm{C}$ 16:1.

On the whole, our results agree well with those of de la Mare $\&$ Shorland (1944). As mentioned before, they examined only one pooled sample, and a closer comparison is therefore not justifiable. 
De Man \& Bowland (1963) identified altogether 10 fatty acids in sow's milk. These acids were also observed and identified in our material. They examined the fatty-acid composition of a colostrum sample and a sample of later milk from each of 5 sows which had been fed a diet containing 4.2 per cent of crude fat. The fatty-acid composition of the food and the length of time which it was fed before delivery are not stated. Grossly, they found the same differences between colostrum fat and fat of later milk as we did. However, differences in animal material and in experimental planning make a closer comparison between their results and ours difficult.

They also gave a diet containing 15 per cent stabilized tallow to 3 sows. This influenced the fatty-acid composition as compared with the afore-mentioned diet.

\section{REFERENGES}

1. Carrol, K. K.: Quantitative estimation of peak areas in gas-liquid chromatography. Nature, 1961, 191, 377.

2. Dahlberg, G.: Statistical methods for medical and biological students, Georg Allen \& Unwin Ltd. London, 1948.

3. De la Mare, P. B. D. \& Shorland, F. B.: Fat of sows milk. Nature 1944, 153, 380.

4. De Man, J. M. \& Bowland, J. P.: Fatty acid composition of sow's colostrum, milk, and body fat as determined by gas-liquid chromatography. J. Dairy Res. 1963, 30, 339.

5. Farquhar, J. W., Insull, W., Rosen, P., Stoffel, W. \& Ahrens, E. H.: The analysis of fatty acid mixtures by gas-liquid chromatography: Construction and operation of an ionization chamber instrument. Nutr. Rev. Suppl. no. 8, 1959, 17, Pt II, 29.

6. Folley, S. J. \& McNaught, M. L.: Biosynthesis of milk fat. Milk: the mammary gland and its secretion. Academic Press, New York and London, 1961, I, 441.

7. Hilditch, T. P.: The chemical constitution of natural fats. 3rd Ed. Chapman \& Hall Ltd. London 1956.

8. Jylling, B. \& Havskov Sørensen, P.: Investigations on the composition of sow milk. Royal Veterinary and Agricultural College Yearbook, Copenhagen, 1960, 20.

9. Keeney, M., Katz, I. \& Allison, M. J.: On the probable origin of some milk fatty acids in rumen microbial lipids. J. Am. Oil Chemists' Soc. 1962, 39, 198.

10. Kishimoto, Y.\& Radin, N. S.: Isolation and determination methods for brain cerebrosides, hydroxy fatty acids, and unsaturated and saturated fatty acids. J. Lipid Res. 1959, 1, 72. 
11. Knodt, C. B. \& Petersen, W. E.: The effect of the complete evacuation of mammary gland by pitocin upon milk and fat production. J. Dairy Sci. 1944, 27, 449.

12. Lindberg, P., Bingefors, S., Lannek, N. \& Tanhuanpä̈, E.: The fatty acid composition of Swedish varieties of wheat, barley, oats and rye. Acta Agricult. Scand. 1964, 14, 3.

13. Luddy, F. E., Barford, R. A. \& Riemenschneider, R. W.: Direct conversion of lipid components to their fatty acid methyl esters. J. Am. Oil. Chemists' Soc. 1960, 37, 447.

14. MacGee, J.: Enzymatic determination of polyunsaturated fatty acids. Anal. Chem. 1959, 31, 298.

15. Pecsoc, R. L.: Principles and practice of gas chromatography. John Wiley and Sons, Inc. New York, 1959.

16. Perrin, D. R.: The composition of sow's milk during the course of lactation. J. Dairy Res. 1954, 21, 55.

17. Tollerz, G. \& Lindberg, P.: Acta vet. scand. 1965, 6 . In press.

\section{SUMMARY}

The fatty-acid composition and the lipid content of sow's milk were studied in 8 sows. Samples were taken shortly after delivery and then at intervals during the period of lactation. Altogether 22 different acids were identified. C 16:0, C 16:1, C 18:1, and C 18:2 dominate quantitatively, constituting about 90 per cent. In the diets used, the first days' milk was poorer in $C$ 14:0, C 16:0, and $C$ 16:1 and richer in $\mathrm{C}$ 18:0 and $\mathrm{C}$ 18:1 than was later milk. Sow's milk is distinct from cow's milk, especially by its lack of, or only trace appearance of, short-chain fatty acids. The long-chain unsaturated acids are relatively abundant.

There is a considerable variation in the values from time to time. The cause of this is probably of inherent metabolic nature.

\section{ZUSAMMENFASSUNG}

\section{Eine Untersuchung, haupsächlich von der Zusammensetzung der Fettsäuren im Milchfett von Säuen.}

Die Zusammensetzung der Fettsäuren und der Lipideninhalt in der Milch von Säuen, wurde bei 8 Säuen untersucht. Die Proben wurden kurz nach dem Ferkeln und danach in Abständen während der Laktationsperiode genommen. Zusammen wurden 22 verschiedene Säuren festgestellt. C 16:0, C 16:1, C 18:1 und C 18:2 sind quantitativ überwiegend und machen ungefähr $90 \%$ aus. Bei den angewendeten Diäten, das Milchfett des ersten Tages war ärmer an C 14:0, C 16:0 und $C$ 16:1 und reicher an $C$ 18:0 und $C$ 18:1 als das Milchfett in späterer Milch. Die Milch der Sau unterscheidet sich von der Kuhmilch besonders dadurch, dass die kurzkettige Fettsäuren ganz fehlen 
oder nur in Spuren vorhanden sind. Die ungesättigte langkettige Säuren sind verhältnismässig reichlich vorhanden.

Von Zeit zur Zeit kommen zwischen den Werten bedeutende Unterschiede vor. Die Ursache dieser Unterschiede sind wahrscheinlich von rein metabolischer Natur.

\section{SAMMANFATTNING}

En undersökning $i$ första hand av fettsyrekompositionen i suggmjölksfett.

Fettsyresammansättning och fettinnehåll i suggmjök från 8 suggor undersöktes. Suggorna mjölkades kort tid efter grisningen och sedan med intervall under hela laktationen. 22 olika fettsyror identifierades. Fettsyrorna C 16:0, C 16:1, C 18:1 och C 18:2 dominerade och representerade c:a $90 \%$ av fettsyrorna. Med de använda kosterna innehöll de första dagarnas mjölk mindre av C 14:0, C 16:0 och C 16:1 och mer av C 18:0 och C 18:1 än fettet $i$ den senare mjölken. Suggmjölk skiljer sig från komjölk speciellt genom att den endast innehåller obetydligt med kortkedjiga fettsyror. De långkedjiga, omättade fettsyrorna är relativt rikligt förekommande.

En ansenlig variation i värdena förefinnes mellan olika provtagningstillfällen. Orsaken till detta torde vara av ren metabolisk natur.

(Received December 23. 1963). 